\title{
КАТЕГОРИЯ КОМИЧЕСКОГО КАК САМОБЫТНАЯ ЦЕННОСТЬ ВОЕННОЙ СУБКУЛЬТУРЫ США
}

\section{THE COMIC CATEGORY AS A DISTINCTIVE VALUE OF THE U.S. MILITARY COMMUNITY}

\section{K. Agaphonova}

Summary: Irrespective of a field of intellectual and labor activities, any professional world view rests on a system of fundamental values. Warrior's ethos is the core of the professional military world outlook. Professional ethos embraces a set of moral and ethical patterns of the military service. The object of this paper is the dimension of values of the military cohort of America's society. The subject area is the U.S. military service members' laughing culture which manifests itself through lexical and phraseological units of the professional sociolect. The analysis delivered in this paper concludes that the category of comic is one of the cornerstone values of the U.S. military milieu.

Keywords: U.S. Armed Forces, military community, army subculture, axiosphere, system of values, military sociolect, army humor, jargon, phraseological unit.
$\mathrm{B}$ ыбор ракурса настоящей работы определяется характером взаимоотношений между компонентами триады «национальная (этническая) общность»«культура» - «язык». В качестве объекта научного исследования выступает система ценностей армейского сегмента американского общества. Предметную область исследования составляет смеховая культура военного социума США, представленная характерными феноменами профессионального социолекта. Выдвигается и подкрепляется аутентичным языковым материалом тезис о том, что наряду с профессиональными универсалиями андрочентризма, дисциплинированности, жертвенности, культа профессионализации вооруженного насилия и примата социальной когезии воинского коллектива, одной из важнейших самобытных ценностей армейской субкультуры выступает категория комического. Языковые феномены смеховой культуры военнослужащих, преломленные сквозь призму реалий военной службы, криптолаличны. Они отражают профессиональную картину мира и содержат в себе систему аллюзий на определенный культурно-исторический контекст. Целью работы ставится выявление и анализ языковых феноменов неформального коммуникативного узуса (арготизмов, жаргонизмов, прецедентных феноменов, фразеологизмов и клишированных оборотов речи), позволяющих запечатлеть особенности аксиосферы социально-профессиональной группы военнослужащих США.

\author{
Агафонова Ксения Юрьевна \\ Преподаватель, ФГКВОУ ВО «Военный университет» \\ Минобороны России \\ bc@mail.ru
}

Аннотация: Независимо от сферы приложения человеческого интеллекта и труда, любая профессиональная картина мира зиждется на системе фундаментальных ценностных ориентиров. Основу профессиональной картины мира военнослужащего составляет воинский этос. Последний являет собой совокупность морально-этических установок военной службы. Объектом научного исследования настоящей статьи избрана аксиосфера армейской части американского социума. Предметную область составляет смеховая культура военнослужащих армии (ША, выраженная в лексико-фразеологических единицах профессионального социолекта. На основании проведенного анализа делается вывод о том, что одной из важнейших ценностей военной субкультуры США выступает категория комического.

Ключевые слова: вооруженные силы США, военный социум, армейская субкультура, аксиосфера, система ценностей, военный социолект, армейский юмор, жаргонизм, ФЕ.

Морально-боевые качества воина - совокупность тесно связанных и дополняющих друг друга черт личности, необходимых для успешного выполнения военнослужащим своих обязанностей как в мирное, так и в военное время. Эталонному архетипу «воина-защитника» присущи такие морально-боевые качества, как верность долгу и военной присяге, дисциплинированность, стойкость, мужество, решительность, инициативность, воинское мастерство, физическая выносливость. Профессиональный образ мира военнослужащего зиждется на системе неподверженных «коррозии» времени ценностей. Последние консервативны, институционально значимы и передаются от одного поколения военнослужащих к другому. Профессиональные и духовные ценности военной службы, полагает А.С. Романов, «выступают в роли сверхличностных морально-этических императивов, определяющих границы высокого и низменного, должного и порицаемого» [4, с. 332-333]. Под ключевыми ценностями военного социума понимаются некие концептуальные ориентиры, эталоны, «составляющие глубинный слой всей интенциональной структуры коллективной идентичности» носителя воинской культуры [Там же, с. 332-333].

Военная субкультура имеет ряд особенностей, обусловленных (а) характером общественно значимой функции вооруженного насилия, (б) культурно-истори- 
ческим наследием военного социума, (в) институциональными особенностями военной службы (речь идет главным образом об иерархии служебно-должностных отношений, профессионально значимых знаниях, умениях, навыках) и, наконец, (г) спецификой особого подъязыка, обслуживающего коммуникативные потребности армейской части общества. Особенности языковой (речевой) культуры представителя «униформированного мира» (формулировку мы заимствуем у Б.Л. Бойко) во многом обусловлены жесткой регламентацией не только профессиональной деятельности, но личного пространства военнослужащего. Порядок речевого поведения начальника и подчиненного, формы воинского приветствия, обращения, доклады и т. д. четко определены положениями нормативно-правовых источников, - воинских уставов. Речь военнослужащих тесно связана с особенностями армейской службы, опытом боевых действий, военно-технической терминологией. Характерные приметы профессионального речевого репертуара выделяют военнослужащих на фоне прочих социальных групп. В современном английском языке за военным социолектом закрепились следующие наименования: lingo, milspeak, military lore, military sublanguage, military vernacular speech, salty language и др.

Как справедливо отмечает Т.Е. Маррэй, для представителей всех видов вооруженных сил, родов войск и служб характерна тенденция к лингвистическому творчеству. Солдаты, моряки, морские пехотинцы, летчики и военнослужащие ВКС США образуют особую субкультуру. Такая устойчивая социальная общность связана не только общими условиями быта, повседневной трудовой деятельности, но и особым профессионально отмеченным мировоззрением, особым вариантом национального языка. Ученый выделяет следующие основные причины обособления специализированных лексиконов (различных видов арго, кэнта и т. д.). Во-первых, особый жаргон отвечает потребностям самоидентификации и формирования социально-психологической когезии членов воинского коллектива. Во-вторых, представители армейской субкультуры стремятся к языковой экономии. Последняя проявляется в том, что многословные, тяжеловесные номинативные обозначения реалий военной службы (например, номенклатур вооружения и военной техники) сводятся к емкому слову, лаконичной фразе или аббревиатуре. И, наконец, в-третьих, опасность и напряженность военной службы, относительная замкнутость военной субкультуры, иерархичность и субординация обусловливают необходимость снятия стресса [12, с. 125-128]. Разрядка достигается в том числе через употребление экспрессивных просторечных, вульгарных или табуированных жаргонизмов. Военный профжаргон нередко груб и фамильярен. Профессиональные жаргонизмы, отмечает А.С. Романов, «отражают недовольство военнослужащих условиями повседневного быта, питанием, тя- готами военной службы. “Юмор цвета хаки” способствует разрядке психоэмоционального напряжения, маскирует насильственный характер профессиональной деятельности» $[4$, с. 150].

Под армейской субкультурой А.В. Проноза понимает «совокупность различных поведенческих фактов армейской жизни (обычаев, традиций, ритуалов, системы рангов военнослужащих и т. д.), характерных художественно-изобразительных форм (карманные блокноты, “дембельские" альбомы, песенники, татуировки на теле и др.); своеобразных вербальных форм, прозаических (жаргон, анекдоты, афоризмы, “крылатые” высказывания) и поэтических (стихотворения, песни, четверостишья, поздравления)» [3, с. 129]. Официально существующая система взаимоотношений между военнослужащими органично дополняется субкультурными элементами. Последние проявляются в условиях сниженного социального контроля.

Военная служба сопряжена с угрозой жизни и здоровью, авторитарностью, жесткой иерархией служебных отношений, дефицитом личного времени, социальными вызовами и иными неблагоприятными факторами. Однако названные факторы военной службы непреодолимы и выступают conditions sine qua non. Именно по этой причине лишенный социального ценза армейский юмор нередко окрашен в мрачные тона, циничен, лишен политкорректности. С одной стороны, жаргонизмы выполняют людическую функцию, связанную с проявлением лингвистического творчества. С другой стороны, смех есть защитная реакция человеческой психики в ответ на деструктивное воздействие ультра-агрессивной среды [8, с. 119-120]. Ср., например, следующие армейские клише юмористического содержания: anything уоu do can get you killed, including nothing - 'всякое действие или бездействие может привести к твоей гибели', there are no atheists in a foxhole - 'безбожников в окопах нет', the enemy invariably attacks on two occasions: when they're ready \& when you're not - 'противник неизменно переходит в наступление в двух случаях: когда к этому готов он, и когда к этому не готов ты', never share a foxhole with anyone braver than yourself - 'никогда не садись в окоп с тем, кто смелее тебя' [7, с. 113]. Черный юмор армейской части общества - дерзкая попытка презреть саму смерть.

Следуя логике изложения материала, далее мы предлагаем подкрепить языковыми примерами изложенный ранее тезис о том, что в лексическом составе профессионального социолекта запечатлены фундаментальные ценности «военного мира». Нами будут рассмотрены такие феномены неформального речевого обихода американских военнослужащих, как жаргонизмы, прецедентные имена, армейские клише и максимы. Анализируемые феномены имеют различную локально-темпоральную отнесенность, однако значительная часть приводи- 
мого материала отражает реалии Второй мировой войны. Иллюстративный материал извлекается методом сплошной выборки из следующих источников: англоязычного словаря военного жаргона War Slang: American fighting words and phrases since the Civil War (Dickson, 2003), двуязычного англо-русского словаря «Сленг что это такое? Английская просторечная военная лексика» (Судзиловский, 1973), специализированных сетевых ресурсов.

В профессиональном жаргоне военного человека немало циничных изречений, связанных с опасностью службы и опытом боевых действий, о чем свидетельствуют следующие примеры. Ср., baptized by fire (to be) - '1. прянять боевое крещение; 2. получить первое боевое ранение' [10, р. 123], barking of the dogs of war - 'артиллерийский обстрел, бомбардировка' (досл. лай псов войны) [lbid., p. 120], bite the dust -'1. потерпеть поражение; 2. погибнуть; 3. получить ранение; покрыться позором' [lbid., p. 127], butch / butcher - 'медик; офицер медицинской службы'(досл.мясник), butcher's bill-'список боевых потерь' [lbid., p. 137], go-away kiss - 'пуля навылет' (досл. прощальный поцелуй) [lbid., p. 166], go to Davy - 'сгинуть в морской пучине' (отправиться на дно к легендарному духа моря, - Дэйви Джоунсу') [lbid., p. 168], roller-skate baby - 'инвалид с ампутированными до колен конечностями [lbid., p. 206], shooting gallery - 'передовая, фронт' (досл. тир) [lbid., р. 211], trigger talk - 'перестрелка' (досл. перекличка спусковых крючков) [lbid., p. 223].

Принимая во внимание тот факт, что служба в вооруженных силах apriori сопряжена с риском, философская категория бытия <...> обретает особое качество. Именно поэтому тематика жизни и смерти в профессиональном жаргоне представлена широко. «В экстремальных условиях боевых действий», - отмечает А.С. Романов, - «понимание собственной экзистенциальности изменяется, и вектор смысла жизни смещается в сторону наджизненного, надбиологического существования» [7, с. 112-113]. Опыт участия в боевых действиях оказывает колоссальное деструктивное влияние на психику военнослужащего, его мировоззренческие позиции и отношение к смерти. Ср., например, такие изречения, как great unknown (the) - '1. смерть, кончина; 2. какойлибо кулинарный изыск, блюдо (шутл.-ирон.) [10, р. 168], praise the Lord and pass the ammunition - 'на Бога надейся, а сам не плошай' [lbid., p. 201], complacency kills / keep your head on a swivel - 'никогда не теряй бдительности' [6], stop a bullet - 'получить пулевое ранение' [9, с. 93], this bullet had my name on it - 'эта пуля была предназначена для меня' [7, с. 166]. Рассмотрим еще один пример. Под устойчивым оборотом buy the farm / buy it понимается гибель военнослужащего при исполнении воинского дол- га. По мнению Ф.А. Хэйли (Soldier talk, 1982), клише было заимствовано у британских военнослужащих во время Второй мировой войны и прочно вошло в речевой обиход американских военных в годы войны на Корейском полуострове (1950-1953 гг.) [10, р. 238, 265]. По одной из версий, объясняющих этимологию изречения, «в случае гибели военнослужащего, семье усопшего предоставлялась денежная компенсация, размер которой позволял приобрести в собственность ферму» [Там же, с. 166].

В самом основании армейского юмора лежат внутригрупповые социальные связи. Именно по этой причине основное содержание армейской жизни - отношения начальствования и подчинения. Не случайно в военных жаргонизмах широко представлены реалии воинского быта, служебные отношения, повседневнаядеятельность войск. Ср., Army Bible - 'воинские уставы' [10, р. 120], boars nest - 'казарма' (досл. логово кабанов) [9, с. 88], book soldier - 'военнослужащий, действующий в строгом соответствии с уставом' [Там же, с. 89], blue nose certificate - 'запись в послужном списке о прохождении службы в условиях Крайнего Севера или Антарктиды', bubble dancing - 'наряд по столовой' [Там же, с. 91], cake and wine - 'содержание в карцере' [Там же, с. 95], dog show - 'проверка личной гигиены ног военнослужащих', dog tag - 'личный нагрудный номер военнослужащего' [10, p. 149], G.l. party / asses and elbows - традиционная уборка казарменного расположения, проводимая ночью в пятницу накануне субботней проверки казарм [lbid., p. 165], Mickey Mouse Rules - '1. мелкие уставные ограничения; 2. канцелярщина, проволочки' (досл. правила Мики Мауса²) [lbid., p. 188], Sam's circus 'вооруженные силы США' (досл. цирк дядюшки Сэма) [lbid., p. 208].

В армейском юморе запечатлены образцы и антиобразцы поведения. Об этом ярко свидетельствуют следующие фразеологические единицы и устойчивые обороты речи. К числу очевидных ценностей армейской среды относятся профессионализм, уверенность в себе, самодостаточность, энергичность. Ср., cool as cucumber / cool hand / cool fish / cool customer - 'хладнокровный и уверенный в себе военнослужащий' [lbid., p. 143], rootin', tootin' son of a gun - 'энергичный человек' [lbid., p. 206], been there, done that - 'пройти огонь, воду и медные трубы' [7, с. 130]. Нерасторопность, леность, хитрость, отсутствие за плечами опыта боевых действий и неумение держать язык за зубами подвергаются осуждению. Ср., carpet knight (soldier) - 'тыловой вояка' [9, с. 6], coffee cooler - 'бездельник, лодырь' [10, p. 142], lame and lazy list - 'список хромых и косых', loose lips sink ships / the slip of a lip may sink a ship / slipped lips sink ships - 'болтать - врагу помогать' [lbid., p. 166],

1 Davy Jones' locker - «рундук Дэйви Джоунса», морская пучина (особенно как место погребения моряков).

2 Mickey Mouse - Микки Маус, персонаж ранних мультфильмов Уолта Диснея, 
low on amps and voltage - 'безынициативный, вялый военнослужащий' [lbid., p. 185], pencil pusher / pencil shover - 'писарь части, клерк' [lbid., p. 196], sleeping Jesus 'лентяй, нерасторопный человек' [lbid., p. 213].

Рассуждая о профессионально маркированной системе ценностей военной субкультуры, представляется важным подчеркнуть крайне негативное отношение воинского коллектива к проявлениям эгоизма его членов. В качестве иллюстрации рассмотрим инвективное клише semper l, fuck the other guy - 'действовать из эгоистичных побуждений, думать только о себе'. Приводимое клише содержит аллюзию к официальному девизу Морской пехоты США "Semper Fidelis" ("Always Faithful") - «Всегда верны». Ср., также, устойчивые выражения субстандарта военного подъязыка fuck you Jack, l am ok - 'твои проблемы - твоя головная боль', to be an only apple in the orchard / to be an only pebble on the beach 'поступать эгоистично' [7, с. 127-128].
Будучи одной из главных ценностей армейского сегмента общества, социально-групповой диалект военнослужащих дает добротный материал для лингвокультурологического анализа. На основании проведенного исследования делается вывод о том, что понимание профессиональной картины мира военного социума во многом находится в предметном поле его смеховой культуры. Монолитной серьезности военной службы противопоставлен смех. Именно благодаря внеофициальному существованию армейский юмор отличается исключительным радикализмом, свободой и беспощадной трезвостью. В заключение приведем цитату М.М. Бахтина. «<...> смех имеет глубокое миросозерцательное значение, это одна из существеннейших форм правды о мире в его целом, об истории, о человеке; это особая универсальная точка зрения на мир; видящая мир по-иному, но не менее (если не более) существенно, чем серьезность» $[1$, c. 78].

\section{ЛИТЕРАТУРА}

1. Бахтин М.М. Творчество Франсуа Рабле и народная культура средневековья и Ренессанса. 2 изд. М.: Худож. лит., 1990. 543 с.

2. Бойко Б.Л. Основы теории социально-групповых диалектов: монография / Б.Л. Бойко. М.: Военный университет, 2008. 184 с.

3. Проноза А.В. Солдатские рифмы - характерный элемент армейской субкультуры / А.В. Проноза // Социологические исследования. 1999 г. № 9. С. 129-131.

4. Романов А.С. Стереотипизация субкультурных констант в аксиологиии социально-группового диалекта (на материале ценностей и реалий военной службы в языковой культуре (ША): дис. ... уч. ст. доктора филол. наук. Шифр научной специальности: 10.02.19. М.: ВУ, 2020. 444 с.

5. Романов А.С. Аксиологический каркас профессионального образа мира военнослужащих США (на материале прецедентных текстов армейского официоза) / А.С. Романов // Профессиональная картина мира. Методология. Варианты. Практика. Коллективная монография / под общ. ред. С.В. Мыскина и Е.Ф. Тарасова. М.: 000 «Агентство социально-гуманитарных технологий», 2020. С. 95-109.

6. Романов А.С., Лупанова Е.В. Дихотомические диады фразеологических единиц как средство выражения ключевых ценностей армейской субкультуры // А.С. Романов, Е.В. Лупанова // Филологические науки в МГИМО:Журнал. № 1 (21) 2020 / Гл. ред. В.А. Иовенко. М.: МГИМО-Университет, 2020. С. 34-30.

7. Романов А.С. Этнические стереотипы армейской субкультурной среды США в знаках языка и культуры: монография / А.С. Романов. М.: Военный университет, 2017.231 c.

8. Романов А.С. Этнический анекдот как средство отражения стереотипов об американских военнослужащих / А. С. Романов // Вестник Российского университета дружбы народов. Серия: Лингвистика, 2013. М., 2013. № 3. С. 113-124.

9. Судзиловский Г.А. Сленг — что это такое? Английская просторечная военная лексика / Г. А. Судзиловский. М.: Воениздат, 1973. 182 с.

10. Dickson P. War Slang: America fighting words and phrases since the Civil War / P. Dickson. 2nd ed. Dulles, Virginia: Brassey's Inc, 2003.428 p.

11. Beforejoiningthemilitary.com. Squids, Jarheads, Grunts, and Other Military Colloquialisms [Электронный ресурс]. Режим доступа: httр://www. beforejoiningthemilitary.com/squids-jarheads-grunts-the-chair-force-and-other-military-stigmas/ (дата обращения: 12.08.20).

12. Murray T.E. The language of naval fighter pilots // American speech. Tuscaloosa, 1986. Vol. 61. № 2. P. 121-129.

(c) Агафонова Ксения Юрьевна (bc@mail.ru) 